\title{
The Effect of HRIS Adoption on Vodafone Egypt Firm's Performance
}

\author{
Dalia Mohamed ElNakib1* ${ }^{*}$, Mohamed A. Ragheb1, Rasha Abd ElAziz Youssef², \\ Abdel Nasser Ghanem ${ }^{1}$ \\ ${ }^{1}$ Graduate School of Business, AAST \& MT, Alexandria, Egypt \\ ${ }^{2}$ Business Information Systems Department, AAST \& MT, College of Management and Technology, Alexandria, Egypt \\ Email: ^dody_rose@yahoo.com,raghebmm67@gmail.com,rasha_a@aast.edu, aahhg@hotmail.com
}

How to cite this paper: ElNakib, D. M., Ragheb, M. A., Youssef, R. A. E., \& Ghanem, A. N. (2021). The Effect of HRIS Adoption on Vodafone Egypt Firm's Performance. Journal of Human Resource and Sustainability Studies, 9, 173-192. https://doi.org/10.4236/jhrss.2021.92012

Received: March 24, 2021

Accepted: April 25, 2021

Published: April 28, 2021

Copyright $\odot 2021$ by author(s) and Scientific Research Publishing Inc. This work is licensed under the Creative Commons Attribution International License (CC BY 4.0).

http://creativecommons.org/licenses/by/4.0/

\begin{abstract}
The purpose of this paper is to present the findings of Pilot Study applied on Vodafone Egypt to examine the Validity and Reliability of HRIS Adoption Impact on Firm's Performance. The Pilot Study is applied through 60 questionnaires responses from 60 participants in Vodafone Egypt in order to test the validity and reliability of Cronbach's alpha to be measured in internal consistency. Through testing research Validity, researcher found; the minimum Spearman's Rho is 0.752 , and the maximum Spearman's rho is 0.949 . All have $P$-Value less than 0.05 . Moreover, through testing Research Research Reliability, the researcher found; the minimum Cronbach's Alpha coefficient is 0.921 , the maximum Cronbach's Alpha coefficient is 0.974 and the overall Cronbach's Alpha coefficient is 0.985 for the 31 items that were analysed together. Therefore, this indicates that the research instrument used for this study is highly reliable as it is more than the generally accepted reliability score of 0.7. The results of this pilot study are in line with previous studies, somehow they are similar.
\end{abstract}

\section{Keywords}

HRIS, Organization Performance, Validity, Reliability, Quantitative

\section{Introduction}

In the past three years, the adoption of Information Technology (IT) innovation behavior in businesses, relating to the adoption of innovation theory, has been a topic of rising interest. A substantial amount of research has been undertaken in an attempt to study and isolate the main factors that determine the adoption of 
IT innovation behavior at the level of the individual firm. Several researchers have developed conceptual models to verify the adoption of IT behavior aspects. However, the majority of these studies have failed to give a complete account of the factors underlying the adoption of IT innovation behavior in general and the adoption of Human Resource Information Systems (HRIS) in particular.

As automated technologies advance, the workplace is changing dramatically. Increasingly, humans are working alongside technology in ever more sophisticated ways. While this creates many business advantages, one of the risks it poses is the dehumanization of the workplace. Ironically, in the HR arena, technology advancement is creating the opportunity to transform the HRIS from an impersonal people-data management system to a system that creates a more human experience in the workplace.

The performance of an organization also depends on its employees, who are a key part of the organization and form the team that works toward achieving the organization's goals.

Organizational performance is the ultimate dependent variable of interest for researchers concerned with just about any area of management. Market competition for customers, inputs, and capital makes organizational performance essential to the survival and success of the modern business.

This research is a descriptive study, which is used to report the characteristics and behavior of a sample of the population. In descriptive studies, data collection is facilitated without changing the environment (Saunders and Townsend, 2016). The descriptive studies explain and demonstrate the results of research. It explains the comprehensive theoretical philosophical frameworks that guide the research. Research methodology includes theoretical frameworks and learning the various techniques that can be used in the conduct of research-tests, experiments, questionnaires and case studies (Saunders and Townsend, 2016). Research methods or techniques refer to the methods that researchers use in performing research operations. It can be said that research methods are mainly used to gather information so that the researcher can use individual data collection method and make corresponding data analysis (mono method); or use more than one-way technical data collection and data analysis (multiple method) (Saunders and Townsend, 2016).

This research is used Mono method. A quantitative research approach is used to collect and analyze all efficient questionnaires outcomes.

\section{Research Aim and Objectives}

As technology improvements in HR system are bringing in more data and key insights into the dynamic of workplaces, workforce planning is becoming an essential business process for organizations of all sizes.

The overall aim of this research is to examine/measure the influence of HRIS Implementations on Vodafone Egypt Performance.

Human Resources Information Systems played a significant role in a compa- 
ny's human resources function. All though, we live and work in the information and computer age. Executing or affecting an operative and efficient Human resources information systems can be sure-fire for human resource to stay on the cutting edge in its bid to deliver more effective and rationalized service.

\section{Literature Review}

Employment of HRIS is designed to improve the effectiveness either in terms of accuracy of information or by using the technology to simplify the processes. It's true when large data sets require reconciliation according to Hendrickson (2003). Onerous manual reconciliation processes can be executed faster and with near perfect accuracy using automated information systems. Ahmer (2013) pointed out that HRIS should not be considered as an expense rather organizations should take it as the amount spent was invested. HRIS packages with less functionality could be costly. The cost of infrastructure to be installed for the implementation of HRIS was also significant in monetary terms. It was concluded that Relative Advantage and Compatibility were positively related to adoption of HRIS. Top Management Support and HRIS Expertise were found to contributors to the decision of HRIS adoption.

HRIS was used mainly for administrative purposes like payroll and employee record keeping, rather than strategic applications like succession planning. He found a tremendous amount of unrealized HRIS potential as very few respondents are using the HRIS strategically to directly improve their competitiveness HRIS was simply viewed as the use of computer hardware and software applications to perform HRM activities Soon and Fedric (2001).

Organizations are becoming increasingly adept at using HRIS and that a correspondingly more strategic role for HR may be emerging, observed by Bondarouk et al. (2009) and Farndale et al. (2009).

The implementation of HRIS is designed to improve the effectiveness either in terms of accuracy of information or by using the technology to simplify the processes. It's true when large data sets require reconciliation, found by Sekhar and Kalwala (2019).

Al Shibly (2011), responded in his research to the call for continuous challenge and test of Human Resources Information Systems (HRIS) success models, based on the previous IS success models, his study presented and validated a comprehensive, multidimensional model of HRIS success, which consists of six success measures: perceived HRIS system quality, perceived HRIS information quality, perceived HRIS ease of use, perceived HRIS usefulness, HRIS satisfaction, HRIS success (net benefit).

The empirical evidence HRIS success was affected by HRIS satisfaction, which, in turn, was influenced by perceived HRIS system quality, perceived HRIS information quality, perceived HRIS ease of use, and perceived HRIS usefulness. 
The impact of Human Resource Information Systems on information flow in the select software companies. The researcher stated that HRIS is also very much useful in the information flow on various domains of HR processes. In this regard an attempt has been made to present various facets/statements on information flow and analyze HRIS impact on information flow in the software companies in Bangalore City. The overall observation and analysis of the data with the help of statistical tools led to the conclusion that the usage of HRIS has a positive impact on various facets of information flow in the software companies and the findings are also supported by statistical tests and analysis thereon, assessed by Nawaz (2012).

Michael et al. (2012) stated that the biggest advantage of HRIS to an organization is its ability to create presentations and reports. The HRIS system holds all information surrounding the organizations human resources initiatives including hiring practices details like a comprehensive listing of all job applicants.

Organizational performance and organizational effectiveness are used interchangeably; the former captures organizational outcomes in three domains: Product performance, financial performance and shareholders return. Whereas latter is broader and covers outcomes specific to efficient operations. On the other hand, balanced scorecards methodology, widely employed by many firms as instruments for internal management control, contributes to the increased awareness to issues related to effectiveness rather than to performance Alexandru (2012: p. 45).

Savalam and Dadhabai (2018) attempted in their research paper to empirically assess the effectiveness of Integrated Human Resource Information System in Mindtree Solutions. As suggested by recent research, the widely accepted is Success Model which is based on HRIS Effectiveness. HRIS Effectiveness is determined by User Satisfaction. Researchers have examined User Satisfaction through assessing User Satisfaction about System Quality, Information Quality of the system as well as System Use. Data from the survey in Mindtree Solutions are pooled to explore the HRIS Effectiveness and the degree of using system by the users. The results of the survey showed that User Satisfaction from Information Quality, System Quality and System Use are respectively 50.3\%, 59.6\%, 67.2\%. Therefore, Integrated Human Resource System has high effectiveness.

Organizations to develop their effectiveness and efficiency must go ahead to two facilitators: Human Resource Management and Information Technology (Talebi et al., 2014, cited in Boudiaf and Belhadj, 2019). The technology evolution has encouraged organizations to adopt human resource information systems (HRIS) (Karikari Ama et al., 2015, cited in Boudiaf and Belhadj, 2019).

A Human Resource Information System (HRIS) “is a systematic procedure for collecting, storing, maintaining, retrieving, and validating data needed by an organization about its human resources-(Cathcart \& Kovach, 1999, cited in Bhuiyan and Gani, 2015). Human resource systems are the organizational support struts that keep internal operations running smoothly-(Horney \& Ruddle, 
1998, cited in Weeks, 2013). Organizations change to new HR information technologies for many good reasons such as: HR may want to take advantage of the corporate intranet, save money through self-service, or acquire the best software for specialized purposes like pension-(Roberts, 1998, cited in Weeks, 2013). The use of an HRIS offers incremental leaps in efficiency and in the response time of many human resource jobs that are traditionally labor intensive. The HRIS helps to eliminate duplication of efforts and to better organize the efforts of the HR staff. The HRIS can even allow the HR staff to shift from data maintenance to the strategic use of human resources.

\section{Research Methodology}

This research is a descriptive study, which is used to report the characteristics and behavior of a sample of the population. In descriptive studies, data collection is facilitated without changing the environment (Saunders and Townsend, 2016). The descriptive studies explain and demonstrate the results of research. It explains the comprehensive theoretical philosophical frameworks that guide the research. Research methodology includes theoretical frameworks and learning the various techniques that can be used in the conduct of research-tests, experiments, questionnaires and case studies (Saunders and Townsend, 2016). This research is used Mono method. A quantitative research approach is used to collect and analyze all efficient questionnaires outcomes.

The two scales used in this research are ordinal (Likert) scales. The questionnaire was divided in three sections; first one is demographics, then second section for the questions of Independent Variable (HRIS), and the third section related to Dependent Variable (Organization Performance) questions. All variables items have been measured using Five-Point Likert Scale, which ranged from "strongly disagree" to "strongly agree.

\subsection{Research Design}

\subsubsection{Sample}

The Researcher targeted the H.R "Senior, Middle Managers and Employees” in Vodafone Egypt.

\subsubsection{Data Analysis}

To test the research hypotheses and to examine the theoretical relationships; a structural equation model (SEM) estimation will be conducted in order to obtain my results and demonstrate them.

\subsubsection{Data Collection and Measurements}

The Pilot Study has applied through 60 questionnaires responses as shown in Table 1 from 60 participants in Vodafone Egypt. All variables items have been measured using Five-Point Likert Scale, which ranged from "strongly disagree" to "strongly agree". 


\subsubsection{Source of Questionnaire}

1) The HRIS Questions source from:

a) Human Resources Information Systems success Assessment: An integrative model

Prof. Haitham Al Shibly, Department of Business Administration, Al Balqa Applied University, As_salt, Jordan.

Published in: Australian Journal of Basic and Applied Sciences, 5(5): 157-169, 2011, ISSN 1991-8178.

b) The employee perception of the Human Resources Information Systems success

Prof. Ammar Husein, Department of Human Resource Management, High Institute of Business Administration, Damascus, Syria.

Published in: International Journal of Business and Management Invention ISSN (Online): 2319-8028, ISSN (Print): 2319-801X http://www.ijbmi.org/, Volume 4 Issue 2, February 2015, PP. 10-15.

2) The Organization Performance source from:

Agarwal (2018), Effect of Talent Management Practices and Organizational Performance on Employee retention: Evidence from Indian IT Firms, IOSR Journal of Business and Management (IOSR-JBM) e-ISSN: 2278-487X, p-ISSN: 2319-7668. Volume 20, Issue 4. Ver. III (April. 2018), PP 42-52.

\subsubsection{The Questionnaire Form}

\section{Demographics}

1) Please specify your age group:

- 25 or under

- $26-40$

- $41-55$

- 56 and above

2) Please specify your Gender:

- Male

- Female

3) Please specify your Department:

- Human Resources (HR) Department

- Others

4) Please specify your Position

- Specialist

- Senior Manager

- Middle Manager

- Other

5) Please specify your Qualification Degree:

- BSc.

- MSc./MBA

- $\mathrm{PhD} . / \mathrm{DBA}$ 
Table 1. The questionnaire form.

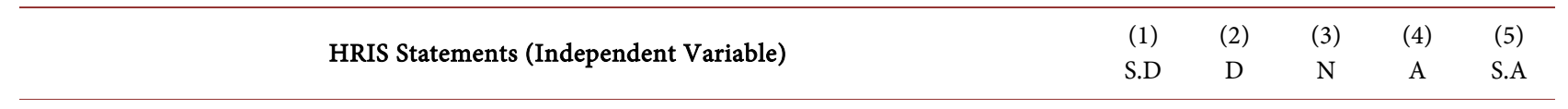

\section{Quality of "HRIS System and Information"}

1) In Your Organization, HRIS makes information very accessible.

2) In Your Organization, HRIS is easy to use the first time you access.

3) In Your Organization, HRIS can flexibly adjust to new work demands.

4) In Your Organization, HRIS returns answers to your requests quickly.

5) In Your Organization, HRIS provides sufficient information.

6) In Your Organization, HRIS provide reports that seem to be just about exactly what you need.

7) In Your Organization, HRIS provide up-to-date information.

8) In Your Organization, you can get form HRIS the information you need in time.

9) In Your Organization, HRIS precise information that you need.

\section{HRIS Perceived Ease of Use and Usefulness}

10) In Your Organization, you find it easy to get HRIS to do what you want it to do.

11) In Your Organization, Using HRIS enables to perform work's requirements more quickly.

12) In Your Organization, Using HRIS improves your job performance and enhances your effectiveness in the job.

\section{HRIS Satisfaction}

13) In Your Organization, HRIS meets the HR requirements of your area of responsibility.

14) In Your Organization, The HRIS is of high quality.

15) In Your Organization, The HRIS has met your expectations.

\section{HRIS Success}

16) In Your Organization, Using HRIS enhances HR Planning.

17) In Your Organization, Using HRIS increases employee benefits.

18) In Your Organization, Using HRIS improves the assessment and training needs.

19) In Your Organization, Using HRIS enhances Industrial Relations.

20) Overall, in Your Organization, Using HRIS enhances Recruitment and Performance Management.

Organization Performance Statements (Dependent Variable)

1) Your Organization's productivity level has increased over the past 3 years.

2) In Your Organization, the Customer Service metrics are very effective.

3) In Your Organization, the Product to Market Time has improved over the past 3 years.

4) Your Organization's Revenues are steadily increasing over the past 3 years.

5) Your Organization's Market Reputation stands out among competitors.

6) Your Organization's Market Share has increased over the past 3 years. 


\section{Continued}

7) In Your Organization, the Employee morale has improved over the past few years.

8) In Your Organization, Employee engagement has increased over the past 3 years.

9) Your Organization's goods/services are of superior quality compared to competitors.

10) In Your Organization, the Work Environment is conducive to good interaction among employees.

11) In Your Organization, Innovation is the key to success.

\subsection{Variables}

\subsubsection{Independent Variable}

HRIS (Human Resources Information Systems) are software or online solution for the data entry, data tracking, and data information needs of the Human Resources, payroll, management, and accounting functions within a business. It is useful for all processes that you want to track and from which you hope to gather useful and purposeful data.

HRIS consists of 4 Dimensions which are as following:

Quality of "HRIS System and Information" determines human resource activities in a proper, systematic and scientific manner; it allows information to be readily accessible to employee, and provides accurate and sufficient information.

HRIS "Perceived Ease of Use and Usefulness" means the easiness of learning how to operate HRIS Software and Applications. It can be achieved through enabling employees to accomplish job's tasks, to perform work's requirements more quickly, for example to increases productivity.

HRIS Satisfaction, which means that HRIS meets the HR requirements of responsibility area, and employees' expectations.

HRIS Success helps to enhance HR Planning, increases employee benefits, improves the assessment and training needs, and to enhance Recruitment and Performance Management.

\subsubsection{Dependent Variable}

\section{Organization Performance}

Organizational performance is related to organizational justice which allows employees to get committed to tasks assigned to him/her and this justice of organization depends on employees trust in the organization that results in employee development as employee get indulges in "high commitment performance management" resulting increase in performance of employee.

\section{Conceptual Framework}

In following section, the researcher is presenting the conceptual Framework as shown in Figure 1 which has been built into one Hypothesis and four Sub Hypotheses.

The researcher used (HRIS) as Independent Variable which is consisted of four dimensions, in order to improve the Dependent Variable (Organization Performance). 


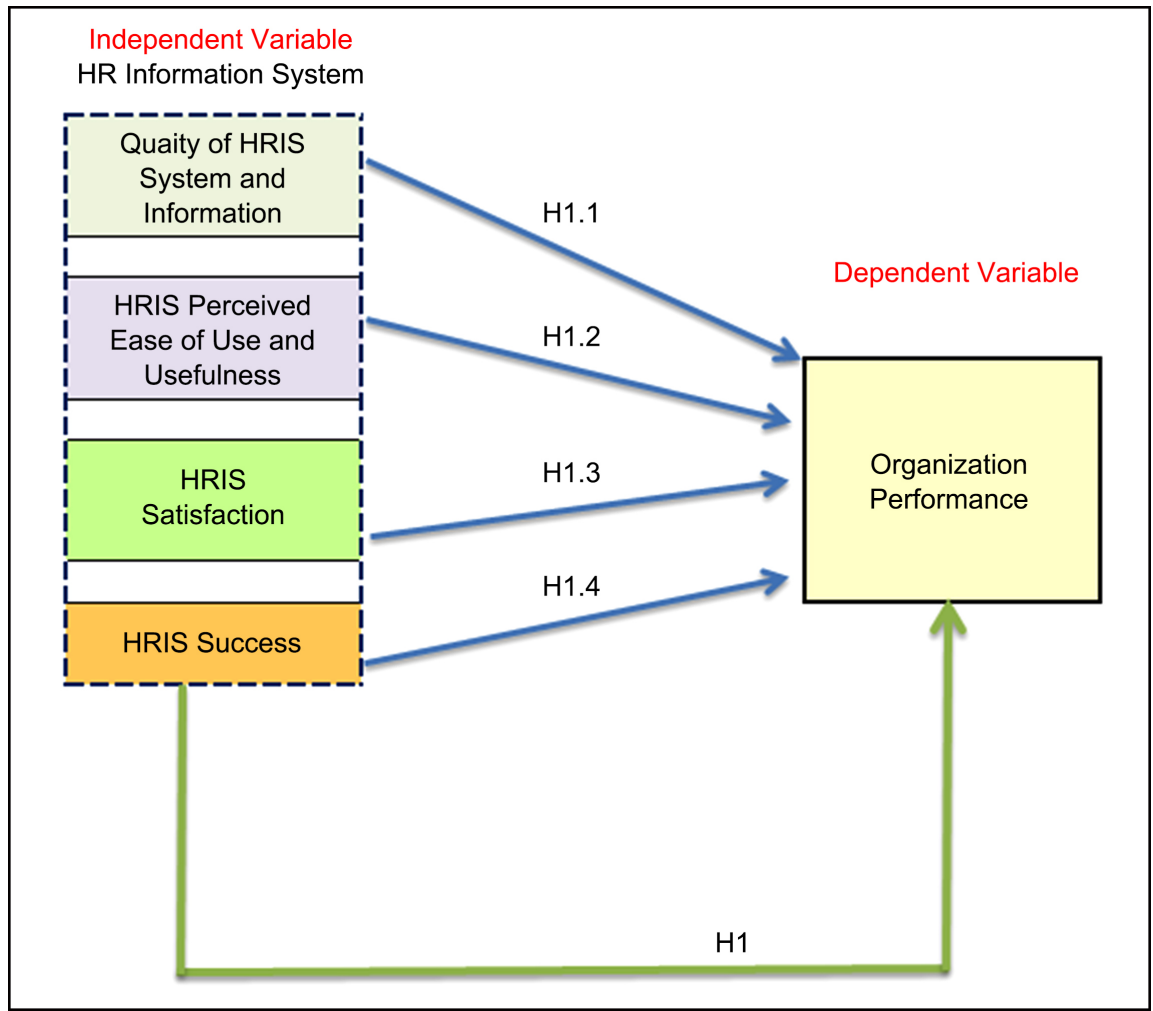

Figure 1. Conceptual framework.

\section{Hypotheses}

Research hypothesis is the statement created when predicting the outcome of research or experiment. The predominant form of data analysis used in participant observation is analytic induction. This may lead to a re-initial hypothesis more than one. Further, deductive methods are used to arrive at a hypothesis that is testable, falsifiable, and realistic (Saunders and Townsend, 2016). In this study, the theoretical framework developed the following hypotheses as follows:

The researcher Conceptual Framework consists of the following Hypothesis and Sub Hypotheses.

$\mathrm{H} 1=$ There is a significant relationship between HRIS and Organization Performance.

H1.1 = There is a significant relationship between Quality of HRIS System and Information and Organization Performance.

H2.1 = There is a significant relationship between HRIS Perceived Ease of Use and Usefulness and Organization Performance.

H3.1 = There is a significant relationship between HRIS Satisfaction and Organization Performance.

H4.1 = There is a significant relationship between HRIS Success and Organization Performance.

To verify the hypotheses, this will be obtained through the Questionnaires outcomes and the output statistical results that will be received from the Structure Equation Model using AMOS Software Package. 
As indicated in Table 2, the references of Theoretical Frame Work and Hypotheses Variables are provided.

Two References are shown in Table 2, the Independent and Dependent Variables Scales References.

Table 2. Research variables and references.

\begin{tabular}{cc}
\hline Variable & Reference \\
\hline $\begin{array}{c}\text { Independent Variable: } \\
\text { Human Resources Information Systems }\end{array}$ & \\
Quality of "HRIS System and Information" & \\
HRIS Perceived Ease of Use \& Usefulness & $\begin{array}{c}\text { Al Shibly (2011), Human Resources Information } \\
\text { Systems Success Assessment: An Integrative } \\
\text { Model, Australian Journal of Basic and Applied } \\
\text { HRIS Satisfaction }\end{array}$ \\
Sciences, 5(5): 157-169, 2011, ISSN 1991-8178. \\
HRIS Success & \\
\hline Dependent Variable: & \\
Organization Performance & $\begin{array}{c}\text { Agarwal (2018), Effect of Talent Management } \\
\text { Practices and Organizational Performance on }\end{array}$ \\
& Employee retention: Evidence from Indian IT Firms. \\
\hline
\end{tabular}

\section{Pilot Study}

The research instrument will be pre-tested before final administration to the respondents. According to Saunders et al. (2016), pre-testing allows errors to be discovered' before the actual collection of data begins $1 \%$ of the population' is considered adequate for pilot study.

In this research, a pilot study was conducted in order to test the employed questionnaire. Testing the questionnaire before using it for data collection is an important step for researchers. Pilot study can be done by identifying a small group of participants who resemble the sample of full study. The aim of pilot testing is to notice the readability problems, to discover confusing instructions, and to uncover questions which make participants uncomfortable (Bryman and Bell, 2011; Cooper and Schindler, 2014). Through pilot tests, researchers can clarify the statements in the questionnaire and improve the flow of content; ultimately it allows researchers to increase reliability and validity of the questions (Saunders et al., 2016).

The Pilot Survey is applied through 60 questionnaires responses from 60 participants on desired Vodafone Egypt Firm in order to test the validity and reliability of Cronbach's alpha to be measured in internal consistency.

Noting that, the minimum sample size to apply any pilot study through is 30 participants in order to run the SPSS Software.

All participants were asked to fill in the questionnaire and provide feedback with regards to clarity and readability of questions in addition to the layout and flow. Consequently, critical feedback was obtained from the participants during 
the pilot study and the questionnaire was revised based on these comments. Some questions were clarified and some of them were repositioned. In addition, the layout and flow of the questions were edited in order to ensure that participants had no problems answering the questionnaire.

\subsection{Research Validity}

Research Validity: Validity should not be confused with reliability and according to Bryman and Bell (2011) it is one of the most important criteria of research. There are many types of validity as suggested by Bryman and Bell (2011).

Saunders et al. (2016) suggested four tests of validity for survey research. They are content' validity, face validity, criterion validity and construct validity. Content validity seeks to test precisely the illegibility of the contents of the phenomenon under investigation. Face validity ensures that a test measures what it was set out to measure. Criterion validity is a measure of how well one variable or a set of variables predict an outcome based on information from other variables of the study. Finally, construct validity tests how well the constructs' measure the theoretical concept under investigation. To test for the content validity, copies of the draft questionnaire were first passed to the researcher's supervisor and three other academics. In order to test the research validity, the Spearman's Rho test will be applied.

Spearman's Rho, which is often represented with the Greek letter $\rho$, is designed to measure the strength and direction of the relationship between two ordinal variables, but is also used when one variable is ordinal and the other is interval/ratio. It is exactly the same as Pearson's $r$ in terms of the outcome of calculating it, in that the computed value of rho will be either positive or negative and will vary between 0 and 1 (Bryman \& Bell, 2011). Table 3 includes the research validity test results by Analysis of 60 Questionnaires:

The minimum Spearman's Rho is 0.752 , and the maximum Spearman's rho is 0.949. All have $P$-Value less than 0.05 .

\subsection{Research Reliability}

Research Reliability: According to Bryman and Bell (2011), reliability is most important to quantitative methods where researchers are concerned about whether the measures are stable or not. Reliability refers to the capability of repeating a study in order to reach consistency.

Cronbach's alpha is a commonly used test of internal reliability. It essentially calculates the average of all possible split-half reliability coefficients. The correlation establishes how closely respondents scores on two groups of indicators are related (Bryman and Bell, 2011).

According to Sekaran and Bougie (2016), the closer the reliability coefficient gets to 1.0, the better. In general, reliabilities less than 0.60 are considered to be poor, those in the 0.70 range, acceptable, and those over 0.80 good. Table 4 includes the test of re-test reliability results by analysis of 60 questionnaires: 
Table 3. Testing validity results: Source from Primary Collected data of 60 respondents.

\begin{tabular}{|c|c|c|c|}
\hline Variable & Question & $\begin{array}{l}\text { Spearman's } \\
\text { Rho }\end{array}$ & $\begin{array}{l}\text { Significance } \\
\text { Level }\end{array}$ \\
\hline \multirow{9}{*}{$\begin{array}{l}\text { Quality of "HRIS } \\
\text { System and } \\
\text { Information" }\end{array}$} & $\begin{array}{l}\text { In Your Organization, HRIS makes } \\
\text { information very accessible. }\end{array}$ & 0.872 & 0.000 \\
\hline & $\begin{array}{l}\text { In Your Organization, HRIS is easy to use the } \\
\text { first time you access. }\end{array}$ & 0.817 & 0.000 \\
\hline & $\begin{array}{l}\text { In Your Organization, HRIS can flexibly } \\
\text { adjust to new work demands. }\end{array}$ & 0.870 & 0.000 \\
\hline & $\begin{array}{l}\text { In Your Organization, HRIS returns answers } \\
\text { to your requests quickly. }\end{array}$ & 0.888 & 0.000 \\
\hline & $\begin{array}{l}\text { In Your Organization, HRIS provides } \\
\text { sufficient information }\end{array}$ & 0.845 & 0.000 \\
\hline & $\begin{array}{l}\text { In Your Organization, HRIS provide reports that } \\
\text { seem to be just about exactly what you need }\end{array}$ & 0.851 & 0.000 \\
\hline & $\begin{array}{l}\text { In Your Organization, HRIS provide } \\
\text { up-to-date information. }\end{array}$ & 0.785 & 0.000 \\
\hline & $\begin{array}{l}\text { In Your Organization, you can get form HRIS } \\
\text { the information you need in time }\end{array}$ & 0.752 & 0.000 \\
\hline & $\begin{array}{l}\text { In Your Organization, HRIS precise } \\
\text { information that you need }\end{array}$ & 0.852 & 0.000 \\
\hline \multirow{3}{*}{$\begin{array}{l}\text { HRIS Perceived } \\
\text { Ease of Use and } \\
\text { Usefulness }\end{array}$} & $\begin{array}{c}\text { In Your Organization, you find it easy to get } \\
\text { HRIS to do what you want it to do }\end{array}$ & 0.927 & 0.000 \\
\hline & $\begin{array}{l}\text { In Your Organization, Using HRIS enables to } \\
\text { perform work's requirements more quickly }\end{array}$ & 0.905 & 0.000 \\
\hline & $\begin{array}{l}\text { In Your Organization, Using HRIS improves } \\
\text { your job performance and enhances your } \\
\text { effectiveness in the job. }\end{array}$ & 0.949 & 0.000 \\
\hline \multirow{3}{*}{ HRIS Satisfaction } & $\begin{array}{l}\text { In Your Organization, HRIS meets the HR } \\
\text { requirements of your area of responsibility }\end{array}$ & 0.949 & 0.000 \\
\hline & $\begin{array}{c}\text { In Your Organization, The HRIS is of high } \\
\text { quality. }\end{array}$ & 0.906 & 0.000 \\
\hline & $\begin{array}{c}\text { In Your Organization, The HRIS has met } \\
\text { your expectations. }\end{array}$ & 0.925 & 0.000 \\
\hline \multirow{5}{*}{ HRIS Success } & $\begin{array}{c}\text { In Your Organization, Using HRIS enhances } \\
\text { HR Planning }\end{array}$ & 0.883 & 0.000 \\
\hline & $\begin{array}{c}\text { In Your Organization, Using HRIS increases } \\
\text { employee benefits }\end{array}$ & 0.856 & 0.000 \\
\hline & $\begin{array}{l}\text { In Your Organization, Using HRIS improves } \\
\text { the assessment and training needs }\end{array}$ & 0.927 & 0.000 \\
\hline & $\begin{array}{l}\text { In Your Organization, Using HRIS enhances } \\
\text { Industrial Relations }\end{array}$ & 0.923 & 0.000 \\
\hline & $\begin{array}{c}\text { Overall, in Your Organization, Using HRIS } \\
\text { enhances Recruitment and Performance } \\
\text { Management }\end{array}$ & 0.916 & 0.000 \\
\hline
\end{tabular}




\section{Continued}

\begin{tabular}{|c|c|c|c|}
\hline & $\begin{array}{l}\text { Your Organization's productivity level has } \\
\text { increased over the past } 3 \text { years }\end{array}$ & 0.901 & 0.000 \\
\hline & $\begin{array}{l}\text { In Your Organization, the Customer Service } \\
\text { metrics are very effective }\end{array}$ & 0.926 & 0.000 \\
\hline & $\begin{array}{l}\text { In Your Organization, the Product to Market } \\
\text { Time has improved over the past } 3 \text { years }\end{array}$ & 0.912 & 0.000 \\
\hline & $\begin{array}{l}\text { Your Organization's Revenues are steadily } \\
\text { increasing over the past } 3 \text { years }\end{array}$ & 0.876 & 0.000 \\
\hline & $\begin{array}{l}\text { Your Organization's Market Reputation } \\
\text { stands out among competitors }\end{array}$ & 0.891 & 0.000 \\
\hline \multirow{6}{*}{$\begin{array}{l}\text { Organization } \\
\text { Performance } \\
\text { Statements }\end{array}$} & $\begin{array}{l}\text { Your Organization's Market Share has } \\
\text { increased over the past } 3 \text { years }\end{array}$ & 0.901 & 0.000 \\
\hline & $\begin{array}{l}\text { In Your Organization, the Employee morale } \\
\text { has improved over the past few years }\end{array}$ & 0.914 & 0.000 \\
\hline & $\begin{array}{c}\text { In Your Organization, Employee engagement } \\
\text { has increased over the past } 3 \text { years }\end{array}$ & 0.917 & 0.000 \\
\hline & $\begin{array}{l}\text { Your Organization's goods/services are of } \\
\text { superior quality compared to competitors }\end{array}$ & 0.825 & 0.000 \\
\hline & $\begin{array}{l}\text { In Your Organization, the Work Environment } \\
\text { is conducive to good interaction among } \\
\text { employees }\end{array}$ & 0.889 & 0.000 \\
\hline & $\begin{array}{c}\text { In Your Organization, Innovation is the key } \\
\text { to success }\end{array}$ & 0.870 & 0.000 \\
\hline
\end{tabular}

Table 4. Testing reliability results: Source from Primary Collected data of 60 respondents.

\begin{tabular}{|c|c|c|c|c|}
\hline Variable & $\begin{array}{c}\text { No. of } \\
\text { Questions }\end{array}$ & $\begin{array}{l}\text { Removed } \\
\text { Questions }\end{array}$ & $\begin{array}{l}\text { Cronbach's } \\
\text { Alpha with } \\
\text { removed } \\
\text { Questions }\end{array}$ & Mark \\
\hline $\begin{array}{l}\text { Quality of "HRIS System } \\
\text { and Information" }\end{array}$ & 9 Questions & - & 0.948 & Acceptable \\
\hline $\begin{array}{l}\text { HRIS Perceived Ease of } \\
\text { Use and Usefulness }\end{array}$ & 3 Questions & - & 0.921 & Acceptable \\
\hline HRIS Satisfaction & 3 Questions & - & 0.940 & Acceptable \\
\hline HRIS Success & 5 Questions & - & 0.948 & Acceptable \\
\hline $\begin{array}{c}\text { Organization Performance } \\
\text { Statements }\end{array}$ & 11 Questions & - & 0.974 & Acceptable \\
\hline Overall Variables & 31 Questions & - & 0.985 & Acceptable \\
\hline
\end{tabular}


The minimum Cronbach's Alpha coefficient is 0.921, the maximum Cronbach's Alpha coefficient is 0.974 and the overall Cronbach's Alpha coefficient is 0.985 for the 31 items that were analysed together.

It therefore indicates that the research instrument used for this study is highly reliable as it is more than the generally accepted reliability score of 0.7 .

\section{Structural Equation Modelling (SEM)}

The aim of this study is to evaluate the human resources information system impact on organization performance, and to develop a framework for the relationship between human resources information system and organization performance. Structural Equation Modelling (SEM) is therefore adopted to examine the causal relationships between human resources information system and organization performance.

In this study, the Amos 25 software package (which is a tool box in SPSS) was used to perform the structural equation modelling (SEM) to investigate the inter-relationships between the constructs of the hypothesized model. The SEM is a statistical' technique' that allows assessment of both direct and indirect effects of each variable on the other variables.

According to Hair et al. (2019), Hypotheses Testing Following a confirmatory factor analysis, the valuation of the structural model through testing of the hypotheses underlying our research model was conducted. The SEM technique was chosen because of the nature of the research model and test hypotheses, and due to the mediating effects.

\subsection{Measurement Model}

Structural equation modelling (SEM) is a multivariate technique which combines multiple regression with confirmatory factor analysis (CFA) to examine the series of dependence relationship simultaneously of the hypothesized model. SEM has two mechanisms, namely measurement model, and structural model. The measurement model as shown in Figure 2 is basically meant for the reliability and validity of the latent variables and observed variables, and the structural model is concerned with the path strength and relationship among the latent variable (Hair et al., 2019).

According to Byrne (2016), the estimations of the parameters and the overall fit index of the measurement model are based on the maximum likelihood (ML) method.

According to Hair et al. (2019), the measurement model enables the researcher to use several variables (indicators) for a single independent or dependent variable. In a Confirmatory Factor Analysis (CFA), the researcher can assess the contribution of each scale item as well as incorporate how well the scale measures the concept (reliability). The scales are then integrated into the estimation' of the relationships between dependent and independent variables in the structural model. This procedure is similar to performing a factor analysis of the scale items and using the factor scores in the regression. 


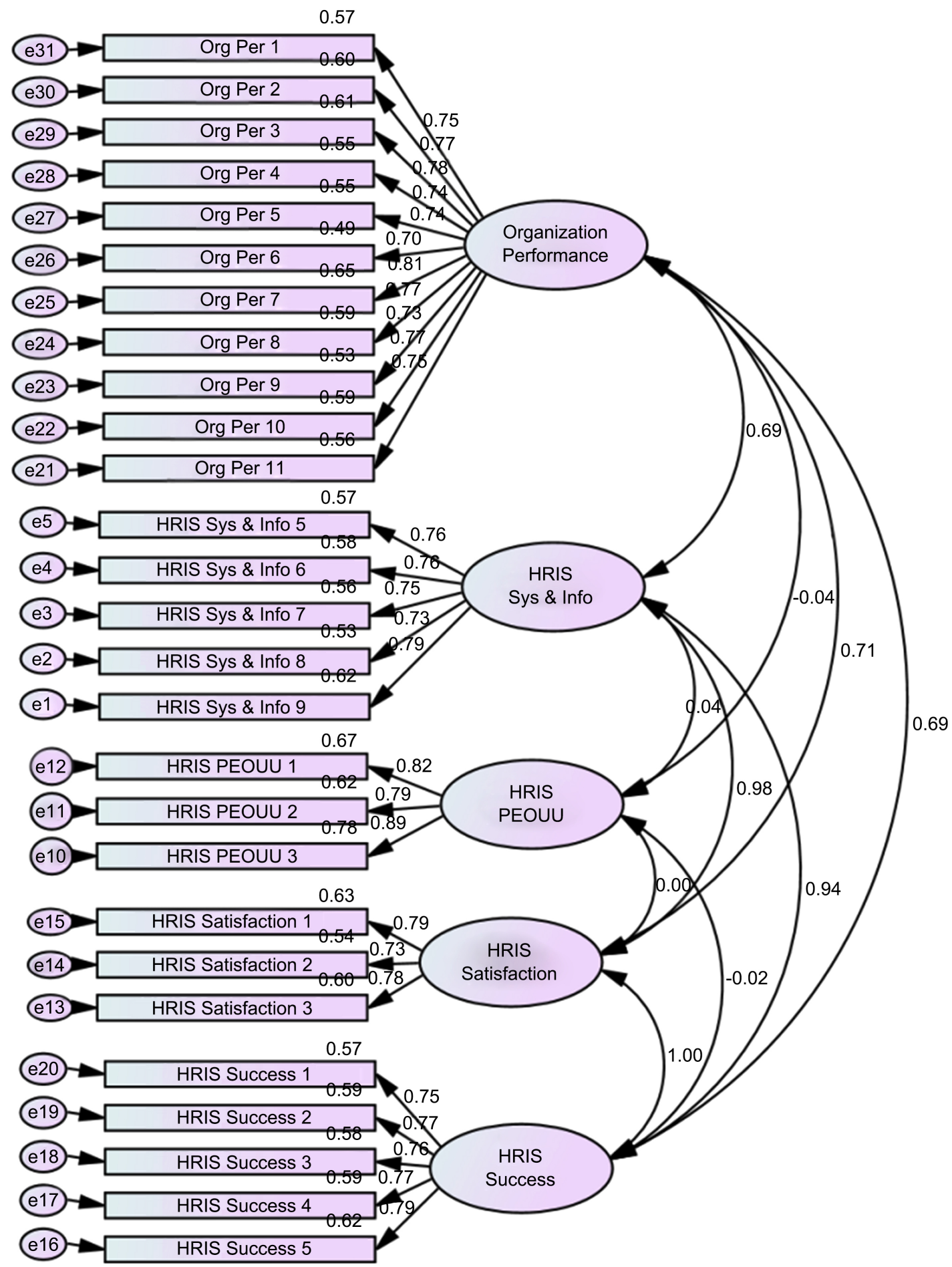

Figure 2. Measurement Model-CFA.

Composite reliability (CR) is used to measure the reliability of a construct in the measurement model. CR is a more presenting way of overall reliability and it determines the consistency of the construct itself (Hair et al., 2019).

The All variances extracted (AVE) should always above 0.50 (Hair et al., 2019). Table 5 shows that All Variances Extracted (AVE) of the particular con- 
structs (HRIS System and Information $=0.572$, HRIS Perceived Ease of Use and Usefulness $=0.690$, HRIS Satisfaction $=0.591$, HRIS Success $=0.590$, Organization Performance $=0.571$ ) are more than 0.500. Overall, these measurement results are satisfactory and suggest that it is appropriate to proceed with the evaluation of the structural model.

Table 5. Model validity measures.

\begin{tabular}{ccc}
\hline Variables & CR & AVE \\
\hline HRIS System and Information & 0.870 & 0.572 \\
HRIS Perceived Ease of Use and Usefulness & 0.869 & 0.690 \\
HRIS Satisfaction & 0.812 & 0.591 \\
HRIS Success & 0.878 & 0.590 \\
Organization Performance & 0.936 & 0.571
\end{tabular}

\subsection{Structural Model}

Structural equation modelling (SEM) is a family of statistical models that seek to explain the relationships among multiple variables. In doing so, it examines the structure of interrelationships expressed in a series of equations, similar to a series of multiple regression equations. These equations depict all of the relationships among constructs (the dependent and independent variables) involved in the analysis. Constructs are unobservable or latent factors represented by multiple variables (much like variables representing a factor in factor analysis). Thus far each multivariate technique has been classified either as an interdependence or dependence technique, SEM can be thought of as a unique combination of both types of techniques because SEM's foundation lies in two familiar multivariate techniques: factor analysis and multiple regression analysis (Hair et al., 2019).

According to Schumacker \& Lomax (2016) using the following five steps: Model specification, Model identification, Model estimation, Testing model fit and Model modification.

Model Specification: Model specification involves determining every relationship and parameter in the model that is of interest to the researcher. Moreover, the goal of the researcher is to determine, as well as possible, the theoretical model that generates a variance-covariance matrix similar to the sample variance-covariance matrix (Schumacker \& Lomax, 2016).

This step involves the specification of a theoretical model that utilizes applicable, related theory and research to determine the latent and observed variables of interest and the relationships among them. In particular, researcher must specify a measurement and structural model. A path diagram can be constructed to visually represent the hypothesized relationships among variable in the theoretical model (Crockett, 2012). 
According to Schumacker \& Lomax (2016); the model should be developed from the available theory and research in the substantive area. This should be the main purpose of the literature review.

The specification of SEM model for this component of the thesis involving theoretical justification of the relationships in the model was established in Chapter Three; the model is evaluating the relationship between the human resources information system (HRIS) and organization performance.

Model Identification: According to Hair et al. (2019) identification refers to the correspondence between the free parameters and the observed variances and covariances. It concerns whether a single, unique value for each and every parameter can be obtained from the observed data in order to prepare for SEM procedure.

A quick check on model identification is whether the Degrees of freedom (DF) are equal to or greater than 1 (Schumacker \& Lomax, 2016). According to Rigdon (1995), Degrees of freedom (DF) reflect the difference between the unique pieces of summary information provided by the data, often called knowns, and the number of parameters that the data are being used to estimate, called unknowns.

Model Estimation: According to Schumacker \& Lomax (2016), in model estimation we need to decide which estimation technique to select for estimating the parameters in our measurement model and structural model.

Such as the standardized path coefficients, in such a way that the observed variance-covariance matrix is optimally adjusted to the predicted moment matrix. "Estimation concerns the procedure to be used to derive the parameter estimates, such as the coefficients and standard errors" (Schreiber et al., 2006).

Model Testing: Having provided the SEM program and sample data along with the measurement and structural models, anyone can check our results and verify our findings. In interpreting our measurement model and structural model, we establish how well the data fit the models. In other words, we examine the extent to which the theoretical model is supported by the sample data. In model testing, we consider model-fit indices for the fit of the entire model and examine the specific tests for the statistical significance of individual parameters in the model (Schumacker \& Lomax, 2016).

\section{Conclusion}

The objective of the study was to find out the adoptions, advantages and challenges in the implementation of HRIS in Vodafone Egypt Firm. This study explored the different dimensions of HRIS to find out how HRIS is used as compared with the previous studies which are conducted in different countries. The purpose of this research is to investigate the proposed researcher's framework.

The pilot study that has undertaken and presented in this research comprises an approach which will influence the main study.

As a result of the elaborated pilot study, researcher has been able to both 
modify instruments and improve the research design which will inform the substantive study. This was a valuable part of the piloting process whereby issues were identified related to the effectiveness of the instruments and the transferability of the model adopted by researcher.

H1 supported what observed in: A Human Resource Information System (HRIS) "is a systematic procedure for collecting, storing, maintaining, retrieving, and validating data needed by an organization about its human resources (Cathcart \& Kovach, 1999, cited in Bhuiyan and Gani, 2015).

Moreover, H1 matched with Michael et al. (2012) stated that the biggest advantage of HRIS to an organization is its ability to create presentations and reports. The HRIS system holds all information surrounding the organizations human resources initiatives including hiring practices details like a comprehensive listing of all job applicants.

Furthermore, H1 agreed with Soon and Fedric (2001) who stated in article "Adoption and Impact of Human Resource Information Systems (HRIS)" that HRIS was used mainly for administrative purposes like payroll and employee record keeping, rather than strategic applications like succession planning. $\mathrm{He}$ found a tremendous amount of unrealized HRIS potential as very few respondents are using the HRIS strategically to directly improve their competitiveness HRIS was simply viewed as the use of computer hardware and software applications to perform HRM activities".

The present study provides managers with empirical support to the practice of designing and employing an effective HRIS in its four dimensions as a mechanism to improve organizational performance. Managers and decision makers should make their HRIS adoption and applications more understandable, authentic, applicable, influential, usable and reliable to increase their HR practices effectiveness.

Future researchers can use HR Talent Analytics or HR Leadership Analytics instead of HRIS, further researches can use Strategic Work Force Planning as Dependent Variable instead of Organization Performance.

Researchers can increase and enlarge the size of their samples from different sectors in Egypt, for example; high educational, petroleum, and financial sectors.

\section{Conflicts of Interest}

The authors declare no conflicts of interest regarding the publication of this paper.

\section{References}

Agarwal, T. (2018). Effect of Talent Management Practices and Organizational Performance on Employee Retention: Evidence from Indian IT Firms. Journal of Internet Banking and Commerce, 23, 1-16.

Ahmer, Z. (2013). Adoption of Human Resource Information System Innovation in Pakistani Organizations. Journal of Quality and Technology Management, 9, 25-50.

Al Shibly, H. (2011). Human Resources Information Systems Success Assessment: An In- 
tegrative Model. Australian Journal of Basic and Applied Sciences, 5, 157-169.

Alexandru, C. (2012). The Impact of Supply Chain Performance on Organizational Performance. Journal of Electrical and Electronics Engineering, 5, 45-48.

Bhuiyan, F., \& Gani, M. (2015). Usage of Human Resource Information System and Its Application in Business: A Study on Banking Industry in Bangladesh. iBusiness, 7, 111-122. https://doi.org/10.4236/ib.2015.73013

Bondarouk, T., Ruël, H., \& van der Heijden, B. (2009). e-HRM Effectiveness in a Public Sector Organization: A Multi-Stakeholder Perspective. International Journal of Human Resource Management, 20, 578-590. https://doi.org/10.1080/09585190802707359

Boudiaf, I., \& Belhadj, T. (2019). The Human Resources Information System and Information Technologies Requirement Case Study: a Sample of Algerian Telecom Agencies. Le système D’information Des Ressources Humaines Et Besoin Des Technologies De L'information: Etude de cas un échantillon d'agences De Télécommunication Algériennes, The Human Resources Information System and Information Technologies Requirement. Finance and Business Economics Review, 3, 20-37. https://doi.org/10.37170/1986-000-009-033

Bryman, A., \& Bell, E. (2011). Business Research Methods. Cambridge; New York, NY: Oxford University Press.

Byrne, B. M. (2016). Structural Equation Modelling with AMOS: Basic Concepts, Applications and Programming (3rd ed.). Mahwah, NJ: Lawrence' Erlbaum.

Cathcart, C., \& Kovach, K. (1999). Human Resource Information Systems (HRIS): Providing Business with Rapid Data Access, Information Exchange \& Strategic Advantage. Public Personnel Management, 28, 275-282. https://doi.org/10.1177/009102609902800208

Cooper, D. R., \& Schindler, P. S. (2014). Business Research Methods (12th ed.). New York, NY: McGraw-Hill.

Crockett, S. A. (2012). A Five-Step Guide to Conducting SEM Analysis in Counseling Research. Counseling Outcome Research and Evaluation, 3, 30-47. https://doi.org/10.1177/2150137811434142

Farndale, E., Paauwe, J., \& Hoeksema, L. (2009). In-Sourcing HR: Shared Service Centres in the Netherlands. International Journal of Human Resource Management, 20, 544-561. https://doi.org/10.1080/09585190802707300

Hair, J. F., Babin, B. J., Anderson, R. E., \& Black, W. C. (2019). Multivariate Data Analysis (8th ed.). England: Pearson Prentice.

Hendrickson, A. R. (2003). Human Resource Information Systems: Back Bone of Technology of Contemporary Human Resources. Journal of Labor Research, 24, 381-394. https://doi.org/10.1007/s12122-003-1002-5

Horney, N., \& Ruddle, I. (1998). All Systems Go? Bank Marketing, 30, 20-26.

Karikari Ama, F., Boateng, P. A., \& Ocansey, E. O. N. D. (2015). The Role of Human Resource Information System in the Process of Manpower Activities. American Journal of Industrial and Business Management, 5, 424-431. http://dx.doi.org/10.4236/ajibm.2015.56042

Michael, J. K., Mohan, T., \& Richard, D. J. (2012). Human Resource Information System (2nd ed.). Thousand Oaks, CA: Sage Publication.

Nawaz, M. (2012). To Assess the Impact of HRIS in Facilitating Information Flow among the Select Software Companies in Bangalore, India. Research Journal of Management Sciences, 1, 1-8.

Rigdon, E. E. (1995). A Necessary and Sufficient Identification Rule for Structural Models 
Estimated in Practice. Multivariate Behavioral Research, 30, 359-383.

https://doi.org/10.1207/s15327906mbr3003_4

Roberts, B. (1998). The New HRIS: Good Deal or \$6 Million Paperweight? HR Magazine, $43,40-44$.

Saunders, M., \& Townsend, K. (2016). Reporting and Justifying the Number of Interview Participants in Organisation and Workplace Research. British Journal of Management, 27, 836-852. https://doi.org/10.1111/1467-8551.12182

Savalam, S., \& Dadhabai, S. (2018). Measuring HRIS Effectiveness. IOSR Journal of Business and Management, 20, 75-81.

Schreiber, Stage, \& King (2006). Reporting Structural Equation Modelling and Confirmatory Factor Analysis Results: A Review. The Journal of Educational Research, 99, No. 6.

Schumacker, R. E., \& Lomax, R. G. (2016). A Beginner's Guide to Structural Equation Modeling (4th ed). New York, NY: Routledge.

Sekaran, U., \& Bougie, R. (2016). Research Methods for Business: A Skill-Building Approach (7th ed.). West Sussex: John Wiley \& Sons

Sekhar, G., \& Kalwala, S. (2019). Effectiveness of Human Resource Information System: A Review of Literature. International Journal of Scientific Research and Review, 7, 2686-2695.

Soon, L. G., \& Fedric, S. A. (2001). Adoption and Impact of Human Resource Information Systems (HRIS). Research and Practice in Human Resource Management, 9, 101-117.

Talebi, J., Karamollah, D., \& Morteza, K. (2014). The Impact of Information Technology on the Performance of the Human Resource in the Martyr Foundation and Veterans Affairs of Great Tehran. Universal Journal of Management.

Weeks, K. (2013). An Analysis of Human Resource Information Systems Impact on Employees. Journal of Management Policy and Practice, 14, 35-49. 